\title{
Performance of starting broiler chicks on sandbox (Hura crepitans) seed meal
} Ozeudu, E; Esonu, B. O. and Emenalom, O. O.

Department of Animal Science and Technology, Federal University of Technology, Owerri, Nigeria.

\begin{abstract}
A21-day feeding trial was conducted to evaluate the feeding value of raw and cooked Sand box (Hura crepitans) seed meal for broiler chickens. Sand box seeds (100kg) were divided into two batches, the first batch was milled raw undicorticated with a hammer mill to produce raw sandbox meal, the second batch was cooked for 60 minutes also undicorticated, sun dried for 48 hours and milled with a hammer mill to produce cooked sandbox meal. Five broiler starter diets were formulated to contain raw and cooked sand box seed meal at $0 \%$, $5 \%$ and $10 \%$ dietary levels respectively. Two hundred and twenty five (225) 14-day old broiler chicks of Marshal breed were divided into five groups of forty five(45) birds each. Each group was further divided into three (3) replicates of fifteen (15) birds each and randomly assigned to the five treatment diet in a completely randomized design (CRD). Data were collected on feed intake, body weight gain and feed conversion ratio. Dietary treatments significantly $(P<0.05)$ influenced feed intake and body weight gain but had no effect $(P>0.05)$ on feed conversion ratio. The results of these studies suggests that sand box (Hura crepitans) seed meal could enhance the performance of broiler starter chicks at 10\% (raw) and $5 \%$ (cooked) dietary levels.
\end{abstract}

Keywords: Sandbox seed meal, Bro1ler starter, performance

\section{Introduction}

The level of animal protein intake in most developing countries of the world is low due to high cost of feed ingredients with its resultant high cost of production. (Esonu et al, 2013).Poultry production represents the fastest means of correcting the shortage of animal protein intake. This is because apart from their high rate of production, poultry has the best efficiency of nutrient transformation into high quality animal protein. Energy feedstuffs constitute between $60 \%$ to $75 \%$ of finished feed for monogastric animals (Enyenihi et al 2013) and currently maize constitutes the bulk of the energy source in finished compound feed. Other grains which are used at a lesser extent include sorghum, millet, wheat, barley, oat, cassava, chips, molasses etc. the difficulty of obtaining foreign exchange in many African Countries has considerably reduced maize importation and other cereals grains for direct human consumption, livestock feed and for industrial use (Esonu et al, 2001). This has therefore resulted in an astronomical increase in the price of grains in recent times. Soya beans (Glycine max) and groundnut (Arachis hypogea) meal are protein sources which play vital roles in the feeding of monogastric animals in Nigeria (Esonu et al, 2014), these feed ingredients are becoming scarce and consequently expensive as a result of high demand due to stiff competition between humans, animal and industrial use, These factors have given rise to the desperate but careful search for non-conventional, locally available and 
low cost, but nutritionally adequate feed resources that do not attract competition between man and animals for livestock production. One of such feed resources is the Sand box (Hura crepitans). The tree (Hura) is a high seed yielding shade tree with a thorny trunk commonly found on roadsides in towns and villages in Nigeria. There have been reports of observations of some free ranging turkeys scrambling to pick and swallow whole seeds as they burst forth from dehiscing fruits (Keay,2010, Yaakugh et al 2001). The nutrient composition of the sand box seeds as reported by Yaakugh et al (2001) shows that the seed has tough seed coat (about $30 \%$ of seed weight) which on removal yielded a product remarkably high in protein (38 $39 \%$ ) fats and oil ( $51 \%$ ) and a much higher level of some essential amino acids like lysine $(5.36 \%)$, methionine $(0.92 \%)$, threonine $(1.92 \%)$, and histidine (1.61\%) compared with the soyabean seed levels (2.67, $0.60,1.68$ and 1.12 respectively). The mineral content is similar to the conventional oilseeds except that it is very low in phosphorus $(0.06-0.08 \%)$. Sandbox seeds contains anti nutritional factors such as tannins, alkaloids, saponins, flavonoids, cyanogenic glucosides and trypsin inhibitors.(Fowomola and Akindahunsi, 2007)

\section{Materials and Methods}

The experiment was conducted at the Teaching and Research Farm of the School of Agriculture and Agricultural Technology, Federal University of Technology Owerri, Imo State, Nigeria. Matured sand box seeds were collected from trees in villages in Ohaji / Egbema Local Government Area of Imo State. The seeds were divided into two batches of $50 \mathrm{~kg}$ each.

The first batch was sun dried for 2 days, crushed raw in a hammer mill to produce the raw sand box meal (RSBM).

The second batch was cooked for one hour at temperature of $100^{\circ} \mathrm{c}$, sun dried for 2 days and crushed in a hammer mill to produce cooked sand box meal (CSBM).

Samples of the processed meals were subjected to chemical analysis (AOAC, 1980 ) to determine its proximate composition

Five (5) broiler starter experimental diets were formulated to contain processed sandbox meal at $0 \%, 5 \%$, and $10 \%$ (RSBXM), $5 \%$ and $10 \%$ (CSBXM) respectively.

Other ingredients were adjusted in such a way that the diets were iso - nitrogenous and met nutrient requirements of the starting broiler chicks (Obioha,1992). Ingredient composition and analysed chemical composition of the diets are presented in table 2 .

Two hundred and twenty-five (225), two week old birds were divided into five groups of 45 birds each and each group was randomly assigned to the five (5) treatment diets in a completely randomized design (CRD). Each group was subdivided into three replicates of fifteen (15) birds and kept in a pen measuring $6 \mathrm{~m} \times 4 \mathrm{~m}$.

Feed and water were provided ad libitum. The compartments were heated using 200 watt electric bulbs. Other routine poultry management procedures were maintained Feed intake was recorded daily, the birds were weighed weekly and feed conversion ratio computed accordingly.

Data collected were subjected to analysis of variance (Snedecor and Cochan 1978). When analysis of variance indicated significant difference, means were compared using Duncan New Multiple Range Test (DNMRT) as outlined by Obi (1990). The trial lasted 21 days.

The proximate composition of sand box 
Ozeudu, Esonu and Emenalom

\begin{tabular}{lcc}
\multicolumn{3}{l}{ Table: 1 Proximate composition of Raw and cooked sand box seed } \\
\hline Components (\%) & *RSBM & \\
\hline Dry Matter & 90.381 & 90.979 \\
Crude protein & 23.696 & 21.507 \\
Crude fibre & 5.659 & 9.300 \\
Ether extract & 7.712 & 2.589 \\
Ash & 6.026 & 5.240 \\
Nitrogen Free Extracts & 52.897 & 45.633 \\
\hline All values expressed on $100 \%$ Dry Matter & &
\end{tabular}

All values expressed on $100 \%$ Dry Matter

*RSBM= Raw SandBox Meal

${ }^{* *} \mathrm{CSBM}=$ Cooked SandBox Meal

seed meal is presented in Table 1 , the nutrient and analysed chemical composition of the experimental diets are shown in Table 2 while data on the performance of the chicks are shown or summarized in Table 3, The average daily feed intake of the experimental groups were $98.6 \mathrm{~g}, 103.0 \mathrm{~g}, 100.0 \mathrm{~g}, 102.5 \mathrm{~g}$ and $77.9 \mathrm{~g}$ for $0 \%, 5 \%$ RSBM , 10\%RSBM, 5\% CSBM and $10 \%$ CSBM diets respectively. Significant difference $(\mathrm{P}<0.05)$ existed among the treatment groups in feed intake. The group on 5\% RSBM recorded the highest feed intake (103.0g) while the group on the $10 \%$ CSBM recorded the least feed intake $(77.9 \mathrm{~g})$.

Body weight gain of the birds followed the same trend as feed intake. The body weight gain of the groups were $38.6 \mathrm{~g}, 40.7 \mathrm{~g}, 42.2 \mathrm{~g}$ , $40.5 \mathrm{~g}$ and $36.5 \mathrm{~g}$ for $0 \%, 5 \% \mathrm{RSBM}, 10 \%$ RSBM, 5\% CSBM and 10\% CSBM respectively. The body weight gain increased with increased level of RSBM while it decreased with increased level of CSBM. This decrease became significant $(\mathrm{P}>0.05)$ at $10 \%$. of CSBM.

There was no significant difference

Table 2: Ingredient Composition of experimental diets (\%)(Starter)

\begin{tabular}{lccccc} 
Ingredients & Control & \multicolumn{2}{c}{$\mathbf{R S B M}$} & \multicolumn{2}{c}{ CSBM } \\
& $\mathbf{0}$ & $\mathbf{5}$ & $\mathbf{1 0}$ & $\mathbf{5}$ & $\mathbf{1 0}$ \\
\hline Maize & 52.00 & 52.00 & 52.00 & 52.00 & 52.00 \\
Soya bean Meal & 25.00 & 20.00 & 15.00 & 20.00 & 15.00 \\
SandBox Meal & 0.00 & 5.00 & 10.00 & 5.00 & 10.00 \\
Palmkernel Meal & 5.50 & 5.50 & 5.50 & 5.50 & 5.50 \\
Wheat offal & 9.00 & 9.00 & 9.00 & 9.00 & 9.00 \\
Blood meal & 3.00 & 3.00 & 3.00 & 3.00 & 3.00 \\
Fish meal & 2.00 & 2.00 & 2.00 & 2.00 & 2.00 \\
Bone meal & 3.00 & 3.00 & 3.00 & 3.00 & 3.00 \\
*Vit /min premix & 0.25 & 0.25 & 0.25 & 0.25 & 0.25 \\
Salt & 0.25 & 0.25 & 0.25 & 0.25 & 0.25 \\
Total & $\mathbf{1 0 0 . 0 0}$ & $\mathbf{1 0 0 . 0 0}$ & $\mathbf{1 0 0 . 0 0}$ & $\mathbf{1 0 0 . 0 0}$ & $\mathbf{1 0 0 . 0 0}$
\end{tabular}

Chemical Analysis

\begin{tabular}{llllll}
\hline Crude protein & 22.22 & 21.97 & 21.85 & 21.97 & 21.79 \\
Ether Extract & 3.82 & 3.77 & 3.73 & 3.77 & 3.73 \\
Crude fibre & 4.63 & 5.56 & 5.50 & 6.56 & 7.50 \\
Ash & 3.48 & 3.49 & 3.49 & 3.49 & 3.49 \\
$\mathrm{ME}(\mathrm{kcal} / \mathrm{kg})$ & 3038.5 & 2975.5 & 2955.5 & 2975.5 & 2954.5 \\
\hline
\end{tabular}

*To provide the following per kg of diet: vit $\mathrm{A}=10,000 \mathrm{u}$,vit $\mathrm{D}_{3}=2000 \mathrm{iu}$, vit $\mathrm{B}_{1}=0.75 \mathrm{mg}$, nicotine $\mathrm{Acid}=25 \mathrm{~g}$, calcium pantothenate $=12.50 \mathrm{mg}$, vitbB $B_{12}=2.5 \mathrm{mg}$, vit $\mathrm{k}_{3}=2.5 \mathrm{mg}$, vit $\mathrm{E}=2.5 \mathrm{mg}$, cobalt $=0.40 \mathrm{mg}$, Biotin $0.50 \mathrm{mg}$, folic acid $=1.00 \mathrm{mg}$, Chlorine- chloride- $25 \mathrm{mg}$, copper $=8.00 \mathrm{mg}$, manganese $=64 \mathrm{mg}$, iron $=32 \mathrm{mg}$, zinc $=40 \mathrm{mg}$, lodine $=$ $0.8 \mathrm{mg}$, flavomycine $=100 \mathrm{mg}$, spiromycin $=5 \mathrm{mg}$, D.L methionine $=50 \mathrm{mg}$, Selenium $=0.16 \mathrm{mg}$, L-Lysine $=120 \mathrm{mg}$. 
Performance of starting broiler chicks on sandbox seed meal

Table 3: Performance of broiler starter (Chicks) fed sand box seed meal

\begin{tabular}{|c|c|c|c|c|c|c|}
\hline \multirow{3}{*}{ Parameters } & \multicolumn{6}{|c|}{ Dietary levels of sand box seed meal (\%) } \\
\hline & \multirow{2}{*}{$\begin{array}{c}\text { Control } \\
0.00\end{array}$} & \multicolumn{2}{|c|}{$\underline{\text { RSBM }}$} & \multicolumn{2}{|c|}{ CSBM } & \multirow[b]{2}{*}{ S E M } \\
\hline & & 5.00 & 10.00 & 5.00 & 10.00 & \\
\hline $\begin{array}{l}\text { Initial body } \\
\text { weight }(\mathrm{g})\end{array}$ & 308.0 & 296.0 & 296.0 & 284.0 & 294.0 & 6.22 \\
\hline $\begin{array}{l}\text { Final body } \\
\text { weight (g) }\end{array}$ & 1390.0 & 1435.0 & 1477.0 & 1425.0 & 1317.0 & 8.50 \\
\hline $\begin{array}{l}\text { Body weight } \\
\text { gain }(\mathrm{g})\end{array}$ & $1087.0^{\mathrm{a}}$ & $1139.0^{\mathrm{b}}$ & $1181.0^{\mathrm{b}}$ & $1134.0^{\mathrm{b}}$ & $1023.0^{\mathrm{a}}$ & 5.30 \\
\hline $\begin{array}{l}\text { Daily body } \\
\text { weight } \\
\text { gain }(g)\end{array}$ & $38.6^{\mathrm{a}}$ & $40.7^{\mathrm{b}}$ & $42.2^{\mathrm{b}}$ & $40.5^{\mathrm{b}}$ & $36.5 \mathrm{a}$ & 3.77 \\
\hline $\begin{array}{l}\text { Daily feed } \\
\text { intake }(\mathrm{g})\end{array}$ & $98.6^{\mathrm{a}}$ & $103.0^{\mathrm{b}}$ & $100.0^{\mathrm{b}}$ & $102.5^{b}$ & $77.9^{\mathrm{a}}$ & 1.55 \\
\hline F C R & 2.6 & 2.5 & 2.4 & 2.5 & 2.1 & 0.50 \\
\hline Mortality & 0.00 & 0.00 & 0.00 & 0.00 & 0.00 & 0.00 \\
\hline
\end{tabular}

$(\mathrm{P}>0.05)$ in feed conversion ratio among the treatment groups. The best feed conversion ratio (2.1) was recorded by the group on $10 \%$ CSBM and poorest (2.6) recorded by the group on $0 \%$ dietary level.

\section{Discussion}

The proximate composition of raw and cooked sandbox meal is shown in Table 1 . The crude protein values of raw and cooked sandbox meals (23.70-21.51) is within that reported for most legumes ( 22.29 27.90\%)(Udedibie and Nkwocha, 1990; Akinmutimi, 2004; Seena et al.,2006).This protein value makes sandbox seed a probable supplement to cereal based diet with crude protein $8.55 \%$ or below (Sagarika et al.,1999) and alternative vegetable protein source than most other unconventional tropical legumes (Seena et al.,2006). The crude fibre content is lesser than Canavalia spp (8.5-17.3\%) (Seena et al. 2006). This level is moderate and makes it desirable and important in diets for farm animals. The lipid value ranges from ( 2.71$7.59 \%$ ) for raw and cooked sandbox seed respectively. This is in line with other unconventional legumes such as swordbean (2.94\%)( Akinmutimi, 2004), Atylosia scarabaevides $(4.56 \%)$ (Arinathon et al.,2003). This high level of ether extract suggest that the seed should be considered as an oil seed as it compares with groundnut $(6.0 \%)$ and higher than soyabean $(3.5 \%)($ P.N.M.P,1995). The Nitrogen free extract (N.F.E) values ( $52.90 \%)$ compared favourably with swordbean ( $50.38 \%$ ) and $\mathrm{Mucun}$ a c o n chinchines is (51.86\%)(Akinmutimi,2004 and Ukachukwu, 2000). The crude protein value of the cooked sandbox seed decreased due to solubilization and leaching of nitrogenous compounds. This might have increased the fibre content of the cooked seeds above the raw seeds (Akande and Fabiyi , 2010). The increase feed intake of the birds on sandbox seed meal over the control except at $10 \%$ dietary level of cooked sandbox meal could be due to high fibre content. Birds must eat therefore to meet their energy requirement to sustain growth and development, hence increased feed intake. This agree with our earlier report (Emenalom et al., 2008). 
Generally, the experimental birds on $10 \%$ raw sandbox seed meal performed better than the groups on control $(0 \%)$ and diets based on cooked sandbox meal respectively. This improved performance could be attributed to the fact that raw sandbox seeds contain amino acids at levels that compared favourably well with soyabean and groundnut seeds and even better in terms of levels of essential amino acids ( Yaakugh et al.,2001). The nutritive value of a protein is dependent on extent to which the composition of its essential amino fulfilled the requirement of the animal being fed. (Benitez, 2001 and Esonu et al., 2006, Olomu and Oboh, 1995.).

Hura crepitans seeds also contain oil which enhances the energy density of the diet for normal maintenance and productive functions, it also serve as a source of essential fatty acids and as well as carrier of the fat-soluble vitamins (Esonu, et al 2004). It had been reported (Yaakugh,2001), that Sandbox contains some essential minerals like; Sodium $(\mathrm{Na})$, Calcium $(\mathrm{Ca})$, Potassium (K) that are of important in the general development of an animal. These probably may have influenced the general improved performance of the birds on the test material at $10 \%$ (RSBM) dietary level over the group on control diet. The poor performance of the birds on $10 \%$ cooked Sandbox seed meal dietary level could be as a result of denaturization of proteins due to heat treatment, solubilization and leaching of some nutrients from the test material (Esonu et al, 2001 and Udedibie etal, 1994) The results of this experiment suggests therefore that raw sandbox seed meal could be used to formulate broiler starter diets at $10 \%$ and cooked sandbox seed meal at 5\% dietary levels respectively.

\section{References}

Akinmutimi, A. H.,( 2004) :Evaluation of
Swordbean (Canavalia gladiata) as an alternative feed resource for broiler chicken Ph.D thesis, College of Animal Science, Michael Okpara University of Agriculture, Umudike, Abia State, Nigeria.

Akande, K. E, and Fabiyi, E. F.,( 2010): Effect of processing methods on some anti-nutritional factors in legume seed for poultry feeding. Int. J. Poultry Sci. 9(10):996-1001.

AOAC 1980. Official methods of Analysis of the Association of Official

Analytical Chemist. $16^{\text {th }}$ edition Association of Analytical Chemist. Washington D.C.

Arinathan , V., Mohan, V. R. and De Britto., A. J,(2003) :Chemical composition of certain tribal pulses in South India. Int. J. Food. Sci. and Nutrition, 54:209-217.

Benitez, L.V. (2001). Amino acid, fatty acid profile in aquaculture nutrition studies. Fish Nutrition Research in Asia.Vol.3 Pp 23-25.

Emenalom, O. O., Udedibie , A. B. I., Esonu, B. O. and Okeudo, N. J. (2008): Effect of cracked-soaked velvet beans ( Mucuna pruriens) on the performance and organ characteristics of finisher broilers.Nig. Agric. J. Vol.39, 131136.

Enyenihi, G.E., Esiegwu,A. C., Esonu, B.O, Uchegbu, M. C and Udedibie, A. B.I.(2013): Gelatinization of fermented cassava tuber meal and its nutritive value for broilers. Nig.J.Anim.Prod.40(2):71-79

Esonu, B.O, Udedibie, A.B.I and Ukorebi, B. A.(1996). Preliminary observation of the effect of two-stage cooking prio to microbial fermentation on nutritive value of 
jackbean ( $C$. ensiformis). For broiler birds. $A M B I O 25 ; 8,537$.

Esonu, B. O., Iheukwumere, F. C., Iwuji, T. C., Akanu, N. and Nwugo, H. O. (2001). Evaluation of Microdesmis puberula leaf as feed ingredients in broiler starter diets. Nig. J. Anim. Prod. 30(1): 3-8.

Esonu, B.O., Azubuike, J.C. and Ukwu, H.O.(2004). Evaluation of Microdesumis puberula leaf as feed ingredient in laying hen diets. Int. J. Poult. Sci.3(2): 96-99.

Esonu, B.O, Agbabiaka, L..A and Osegbue, A.I. (2014): Efficacy of enzyme supplementation of dried rumen digesta for broiler finisher production. Trop.Agric(Trinidad) 91, no.4, 248-255.

Fowomola, M.A. and Akindahunsi, A.A. (2007): Nutritional quality of sandbox tree (Hura crepitans). Linn journal of medicinal food. 10(1); 159-164.

Keay, R. W. J. (2010). Trees of Nigeria. Caledon Press Oxford.

Obi, I.U. (1990). Statistical method of detecting differences between treatment means. $2^{\text {nd }}$ Edition, Snap Press, Enugu.

Obioha, F.C. (1992). A guide to poultry production in the tropics. ACENA publishers Ltd., Enugu.

Olomu, J. M. and Oboh, S. O.(1995). Pig production in Nigeria, Principles and Practices $1^{\text {st }}$ edition. Ajachem Publication, Benin.

Pfizer Nutrient Master Plan ( PNMP) ( 1995): Tropical Crops dicotyledons: Longman Group Ltd London. $1^{\text {st }}$ edition. Pp 242-245.

Saganka, E; Enol, R. J. and Baboo, M. N., ( 1999) : Proximate composition, mineral and amino acid content of mature canavalia gladiate seeds. Food Chemistry, 66: 115-119.

Seena, S., K. R. Sridhar, A. B. Arun and Chichung, Y.( 2006): Effect of roasting and pressure-cooking on nutritional and protein quality of seeds of mangrove legume Canavalia cathartica from South-West coast of India. J. Food composition and Analysis, 19:284-293.

S n e d e c o r, G . W . a n d Cochran,W.G.(1978): Statistical methods. The lowa State University Press, Ames lowa $6^{\text {th }}$ Edition.

Udedibie, A. B. I. and Nkwocha, C. O..(1990):Comparative study of jackbean (Canavalia ensiformis) and Swordbean ( Canavalia gladiate) as protein supplement for young broiler chicks. Nig. J. Amin. Prod. 24: 7-14.

Udedibie, A.B.I., Esonu, B.O., Obaji,C.N. and Durunma, C.S.( 1994):Dry urea treatment prior to toasting as a method of improving the nutritive value of Jackbean (C.ensiformis) for broilers. Anim.Fd.Sci.Tech.48: 335-345.

Ukachukwu, S. N.(2000): Chemical and nutritional evaluation of Mucuna Conchinchinesis (lyon's beans) as an alternative protein ingredient in broiler diets. Ph.D thesis . Dept of Animal Science, University of Nigeria, Nsukka, Nigeria.

Yaakugh, I.D.I, Tuleun, C.D, and Kaankuka, F.G. (2001). Nutrient composition of hura.Bulletin no.5. Department of Animal Production. University of Agriculture Markurdi,. Nigeria. 